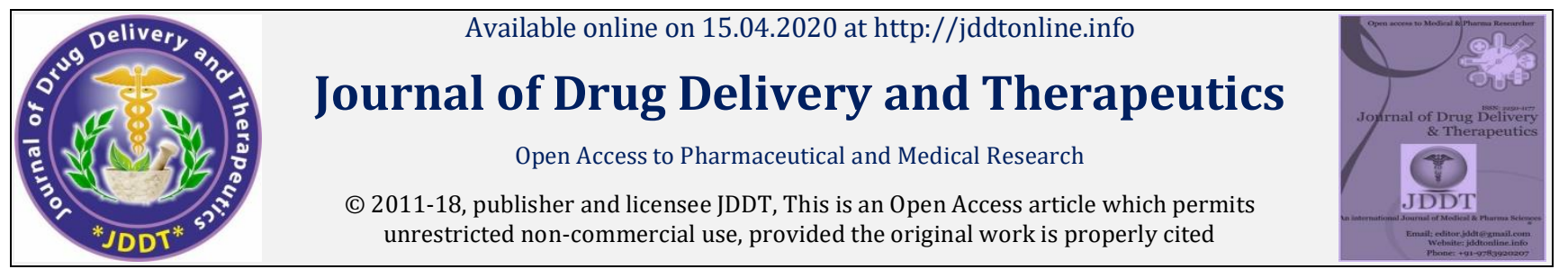

Open 2 Access

Research Article

\title{
The Effect of Green Tea Infusion (Camellia sinensis) on Histopathology of White Rat (Rattus norvegicus) Liver Sprague dawley Strain Induced by Ethanol
}

\author{
Muhartono*, Nabilah Amirah Salsabila, Putu Ristyaning Ayu \\ Department of Pathology, Medical Faculty Lampung University, Lampung, Indonesia
}

\begin{abstract}
Aims: This research aims to determine the effect of green tea infusion (Camellia sinensis) on the hitopathology of white rat liver induced by ethanol.

Method: This study used 30 rats divided into 5 groups as follow negative control group (K1) given aquades, positive control group (K2) given $20 \% 2 \mathrm{~mL} /$ day peroral, treatment group 1, 2, 3 (P1, P2, P3) given $20 \%$ ethanol $2 \mathrm{~mL} /$ day peroral followed by green tea infusion with doses $0,375 \mathrm{~g} /$ day, $0,75 \mathrm{~g} /$ day, and 1,5 g/day single dose per oral for 14 days. The the liver of the rat is taken for microscopic examination. The mean Manja Roenigk scores obtained were $\mathrm{K} 1=1,16, \mathrm{~K} 2=3,36, \mathrm{P} 1=2,8, \mathrm{P} 2=2,68$, and P3=2,56. Data were tested with the Kruskal-wallis test followed by Mann whitney's post hoc test.
\end{abstract}

Results: The results showed a significant mean difference between positive group (K2) and the treatment group P1, P2, and P3. There is no significant mean difference between P1-P2, P1-P3, and P2-P3 which means giving green tea infusion (Cameliia sinensis) in P2 and P3 gave almost the same effect as $\mathrm{P} 1$.

Conclusion: There is an effect of giving green tea infusion (Camellia sinensis) to the histopathology of white rat liver induced by ethanol.

Keywords: antioxidants, ethanol, green tea infusion, liver histopathology.

Article Info: Received 01 Feb 2020; Review Completed 20 March 2020; Accepted 30 March 2020; Available online 15 April 2020

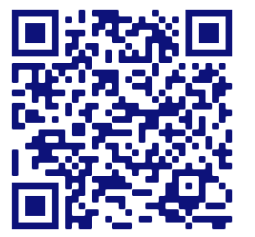

Cite this article as:

Muhartono, Salsabila NA, Ayu PR, The Effect of Green Tea Infusion (Camellia sinensis) on Histopathology of White Rat (Rattus norvegicus) Liver Sprague dawley Strain Induced by Ethanol, Journal of Drug Delivery and Therapeutics. 2020; 10(2-s):90-93 http://dx.doi.org/10.22270/jddt.v10i2-s.4036

*Address for Correspondence:

Muhartono Muhartono, Department of Pathology, Medical Faculty Lampung University, Lampung, Indonesia

\section{INTRODUCTION}

Alcohol, especially in the form of ethyl alcohol (ethanol), has occupied an important place in the history of mankind. Just like in western countries, until the 19th century, alcoholic drinks of the type beer and wine are the most popular drinks. It is believed that alcoholic drinks can provide important calories and nutrients and serves as the main source of daily fluid intake so that alcoholic drinks are widely consumed to date. Nevertheless, excessive consumption can cause disruption to the functions and organs of the body. ${ }^{1}$ Alcohol is a psychoactive substance that can cause addiction. ${ }^{2}$ Low to moderate amounts of alcohol can reduce anxiety and encourage feelings of well-being or even euphorbia. $^{1}$

According to World Health Organization (WHO), in a study in Australia, noted the prevalence of beer consumption was 0,9$11 \%$, wine $7-14 \%$, spirits $37-75,9 \%{ }^{3}$ According to Global Status Report on Alcohol And Health (2014), from 241.000.000 Indonesian populations, the prevalence of disorders due to alcohol use is $0,8 \%$ and the prevalence of alcohol addiction is $0,7 \%$ in men and women. ${ }^{4}$ For the prevalence of frequency of drinking alcohol in Lampung in a month is $42,7 \%$, with the lowest $15,4 \%$ in East Lampung and the highest $66,7 \%$ in Western lampung. ${ }^{5}$ According to Riskesdas (2018), the average number of standard units of alcoholic drinks that are normally drunk on alcohol drinkers aged $\geq 10$ years in Lampung is 5,8 with minimum number 0,1 and maximum 53,4 with total precentage $1,8 \%$ consumption of alcoholic drinks in Lampung. ${ }^{6}$

The main pathway of alcohol metabolism involves alcohol dehydrogenase $(\mathrm{ADH})$, a family of cytosolic enzymes that catalyze the change of alcohol into acetaldehyde. These enzymes are mostly found in the liver and small part are found in the stomach and the brain organs. As the end of the process of alcohol metabolism, alcohol oxidation results in an excess of reducing liver, especially as Nicotinamide Adenosine Dinuclotide Hydrogen (NADH) where excess NADH can cause metabolic disorders such as chronic alcoholism, lactic acidosis, and hypoglycemia in acute alcohol poisoning. The 
main organ damage caused by excessive alcohol consumption is the liver, it also can occur damage to the nervous system, digestion, cardiovascular, and immune. Specific mechanism that are thought to play a role in tissue damage are an increase in oxidative stress, mitochondrial damage, disruption of growth factors, and injury caused by cytokines. ${ }^{1}$

Humans have natural reaction to ward off free radicals in the body, additional antioxidants are also needed as a device when the levels of free radicals in the body are excessive. ${ }^{7,8}$ Consumption of green tea is increasing from year to year, so it needs to be known the various benefits of green tea. ${ }^{9}$ Green tea (Camellia sinensis) is one type of herbal tea that has polyphenol in large quantities, especially catechins, which has high antioxidant activity.8,10

Polyphenol has antioxidant levels 100 times more effective than vitamin $\mathrm{C}$ and 25 times more effective than vitamin $\mathrm{E}$. In addition, polyphenol is also thought to have antiinflammatory and anti-allergic activities. ${ }^{11}$ Based on experimental research studies on rats, the results show that in experimental group who were given ethanol and black tea had organ improvement compared to the group that was only given ethanol. Where in this research, the improvement of black tea was thought to be an activity of the antioxidant catechin. ${ }^{8}$

This research was conducted to see the role of green tea infusion as an antioxidant in preventing oxidative stress that can be seen in the histopathological picture of white rat liver induced with ethanol in a certain time and dose.

\section{MATERIAL AND METHOD}

This research was an experimental study using posttest only controlled group design. This research was conducted for 14 days at Animal House Faculty of Medicine Lampung University and Histology and Anatomy Pathology Faculty of Medicine Lampung University.

The population in this study were white rats that were included in the inclusion and exclusion criteria. Inclusion criteria in this research were white rats Sprague dawley strain male, 8-10 weeks of age, 200-300 gram body weight, normal behaviour and activities and no anatomical abnormalities were found. Exclusion criteria in this research were rat that experienced weight loss $>10 \%$ after adaptation period and rat died during the research period. The research sample was calculated using the Frederer formula and divided into 5 groups so it was obtained sample of 25 rats. To avoid the occurrence of drop out so that each group was added one rat so that the number of rats in this research were 30 .

Before the treatment period, rats were first adapted for 7 days. Then the grouping of experimental animals was carried out with randomization techniques using a group divider application. The treatment group included negative control group (K1) that was given aquades and standard feed, positive control group (K2) that was given ethanol $20 \%$ as much as $2 \mathrm{~mL} /$ day, treatment groups P1, P2, and P3 were given ethanol $20 \%$ as much as $2 \mathrm{~mL} /$ day and continued with giving green tea infusion with consecutive doses 0,375 $\mathrm{g} /$ day, 0,75 g/day, and 1,5 g/day. Hispathological picture of the liver seen with a light microscope using 400x magnification in five fields of view. The measuring scale used Manja Roenigk's scale with the score included, 1=normal, $2=$ cloudy swelling degeneration, 3 =hydropic degeneration, $4=$ necrosis.

Data analysis used Shapiro-Wilk normality test $(p>0,05)$ and Levene's homogeneity test $(p>0,05)$, then continued with Kruskal Wallis non-parametric test $(p<0,05)$ and continued with Post Hoc Mann Whitney analysis $(p<0,05)$. This research was approved by The Ethics Research and Health Committee of the Faculty of Medicine Lampung University with the number 3908/UN26.18/PP.05.02.00/2019.

\section{RESULTS}

During the research there was one rat that dropped out in group K2. After 14 days treatment period rats were terminated using ketamine-xylazine then the liver were taken and the rats were buried. Preparations were made in the liver organ then observed under a light microscope with a magnification 400x.

The following are histopathological pictures of the liver of rats in each experimental group:
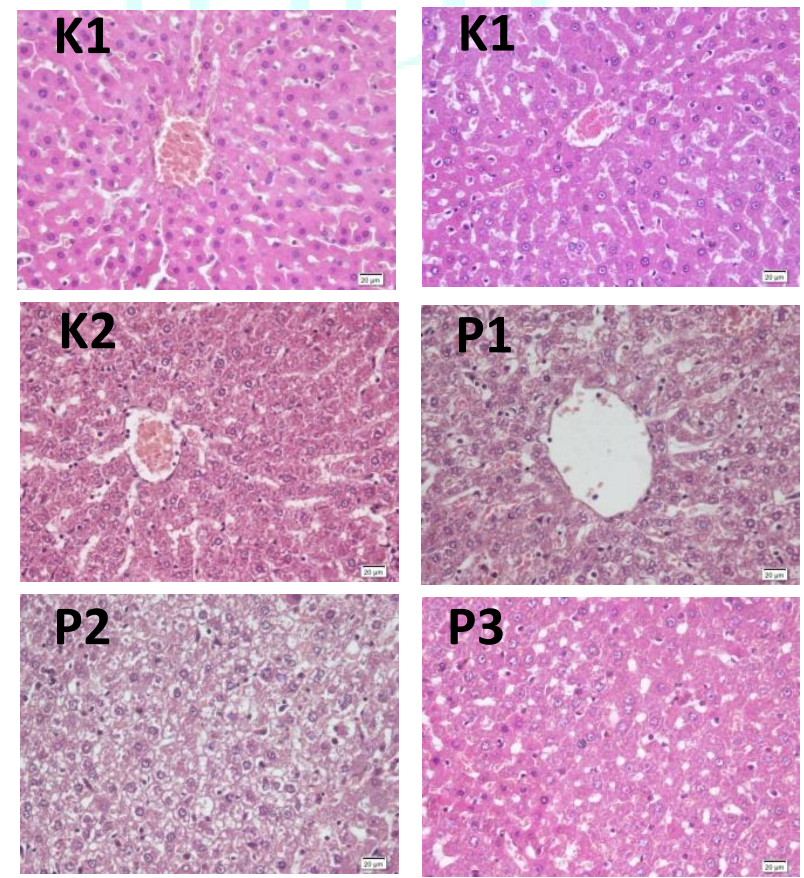

Picture 1. Histopathological picture of rat's liver (400x) 


\section{Muhartono et al}

Group K1 given aquades and standard feed every day obtained normal pictures of histopathology. Negative control group was a group that was not given any treatment, only given rat feed and drink aquades. In the negative control group, normal hepatic histopathology was obtained. Hepatocyte cells seemed normal, properly arranged radier with central vein as its center. No swelling in hepatocyte cells were seen. Liver sinusoid also seemed normal, no visible enlargement and radier patterned which was centered in the central vein.

Positive control group was a group that was given treatment of giving $20 \%$ ethanol with dose $2 \mathrm{~mL} /$ day orally using a sonde for 14 days. Histopathological picture of positive control group (K2) can be seen in the image below. In the histopathological picture found the damage to hepatocyte cells, such as hydropic degeneration, infiltration of inflammatory cells and found necrosis in hepatocyte cells.

Group of treatment 1 was a group that was given treatment of giving $20 \%$ ethanol with dose $2 \mathrm{~mL} /$ day using oral sonde continued with infusion of green tea (Camellia sinensis) with dose 0,375 gr/day using oral sonde for 14 days. In the histopathological picture showed that hepatocyte cells still showed cloudy swelling degeneration, hydropic degeneration, and necrosis but were not as massive as those seen in the positive control group (K2).

Group of treatment 2 was a group that was given treatment of giving $20 \%$ ethanol with dose $2 \mathrm{~mL} /$ day using oral sonde and continued with infusion of green tea (Camellia sinensis) with dose $0,75 \mathrm{~g} /$ day using oral sonde for 14 days. In the histopathological picture found hepatocyte cells that were still experiencing hydropic degeneration and cloudy swelling degeneration but not as massive as in the $\mathrm{K} 2$ group.

Group of treatment 3 was a group that was given treatment of giving $40 \%$ ethanol with dose $2 \mathrm{~mL} /$ day using oral sonde and continued with infusion of green tea (Camellia sinensis) with dose 1,5 g/day using oral sonde for 14 days. In the histopatological picture seemed hepatocyte cells that were still showed hydropic degeneration and cloudy swelling degeneration but not as massive as in the positive control group (K2).

The average results of liver histopathological analysis using Manja Roenigk scores obtained the average in group $\mathrm{K} 1=1,16$, in group $\mathrm{K} 2=3,36$, in group $\mathrm{P} 1=2,8$, in group $\mathrm{P} 2=2,68$, and in group $\mathrm{P} 3=2,56$. Based on the average research it was found that there was a decrease in the average liver damage of rats given infusion of green tea with multilevel doses compared to the average liver damage which was only given ethanol.

Table 1. Shapiro-Wilk Normality Test

\begin{tabular}{cccc}
\hline \multirow{2}{*}{ Groups } & \multicolumn{3}{c}{ Shapiro-Wilk } \\
\cline { 2 - 4 } & Statistic & Df & Sig. \\
\hline K1 & .881 & 5 & .314 \\
K2 & .881 & 5 & .314 \\
P1 & .821 & 5 & .119 \\
P2 & .684 & 5 & .006 \\
P3 & .881 & 5 & .314 \\
\hline
\end{tabular}

According to table 1. Data analysis was performed using Shapiro-Wilk normality test due to sample $<50$. In this normality test the results were not normally distributed so
Journal of Drug Delivery \& Therapeutics. 2020; 10(2-s):90-93

the transformation test was performed but the data was still not normally distributed.

Table 2. Levene's Test

\begin{tabular}{cc}
\hline Levene Statistic & Sig. \\
\hline, 412 &, 798 \\
\hline
\end{tabular}

According to table 2. After conducting normality test, then a homogeneity test was performed to see whether the data was homogeneous or not. In that test, the value $p=0,978$ $(p>0,05)$ was obtained then it can be concluded that the data was homogeneous.

Table 3. Kruskal Wallis Hypothesis Test

\begin{tabular}{cc}
\hline & Data \\
\hline Chi-Square & 20,277 \\
Df & 4 \\
Asymp. Sig. &, 000 \\
\hline
\end{tabular}

According to table 3. Hypothesis test using Kruskal Wallis alternative test and the results obtained $p=0,000(p<0,005)$ so it can be concluded that hypothesis was accepted.

Table 4. Post Hoc Mann Whitney Test

\begin{tabular}{cccccc}
\hline Groups & K1 & K2 & P1 & P2 & P3 \\
\hline K1 & - & $0,008^{*}$ & $0,008^{*}$ & $0,008^{*}$ & $0,008^{*}$ \\
K+ & $0,008^{*}$ & - & $0,008^{*}$ & $0,008^{*}$ & $0,008^{*}$ \\
P1 & $0,008^{*}$ & $0,008^{*}$ & - & 0,307 & 0,082 \\
P2 & $0,008^{*}$ & $0,008^{*}$ & 0,307 & - & 0,212 \\
P3 & $0,008^{*}$ & $0,008^{*}$ & 0,082 & 0,212 & - \\
\hline
\end{tabular}

According to table 4. Post Hoc analysis results obtained a significant value of group K1 against K2, P1, P2, and P3. Group P1, P2, and P3 means to group K1 and K2. There was no significant difference between groups P1, P2, and P3.

\section{DISCUSSION}

Damage to the liver can be caused by several factors. Stress causes a decrease in hepatic blood flow. Hypoxia in the liver tissue causes the formation of ROS in the mitochondria, thus causing endoplasmic reticulum stress that causes the formation of necrotic cells. Stress can also cause an increase in kupffer cell production through excessive entry of LPS and norepnifrin. Activation of these kupffer cells causes the release of inflammatory cells in liver tissue, such as IL-1 and reactive oxidative stress (ROS) including neutrophil cells which can cause inflammation in liver cells. 12

Alcohol will activate kupffer cells and release cytokine cells such as, TNF- $\alpha$, IL-1, IL-6, dan IL-8 so it will cause inflammation in hepatocyte cells. Alcohol metabolism which consists of three pathways ADH, MEOS, and mitochondrial catalase, each has a mechanism that can cause liver cells damage.1,14 ADH pathway produces acetaldehyde which is reactive and highly toxic product that can cause cell damage. MEOS pathway involves cytochrome enzymes P450 (CYP2E1), 2E1, 1A2, and 3A4.1

Indirectly, the mechanism of damage is thought to result from the induction of the cytochrome P450 (CYP2E1) from MEOS pathway. Excessive alcohol consumption can causing 


\section{Muhartono et al}

increased MEOS activity. ${ }^{14-16}$ Ethanol metabolism through the MEOS pathway causes the activation of certain toxins such as $\mathrm{CCL}_{4}, \mathrm{H}_{2} \mathrm{O}_{2}$ formation, $\mathrm{ROS}$, and an increase in NADP+, this causes the NADPH mechanism to inhibit GSH regeneration thus increasing oxidative stress. ${ }^{15}$ Cytochrome enzyme P450 also causes tumor necrosis factor (TNF- $\alpha$ ) release which contributes to necrosis and inflammation of the liver. The process will cause damage to hepatocyte cells and cause inflammation of the liver tissue. ${ }^{14}$

Cloudy swelling degeneration changes in the size of swollen cells and the cytoplasm becomes cloudy. Besides being cloudy, cytoplasm also has granules because it contains a lot of water as the result of the inability of cells to become hemostatic fluids and ions. ${ }^{17}$ According to Mitchell et al (2014), changes occur such as changes in the mitochondria and dilatation of the endoplasmic reticulum which is the main product of oxidative metabolism. ${ }^{18}$ The damage will cause the cell oxidation process to be disrupted which causes the inability of cells to eliminate the results of metabolites so that, there is accumulation of water in the cytoplasm and causes cells to swell. ${ }^{17}$

In some cells there is a shift in extracellular water into the cell, due to interference with ion and volume regulation due to loss of ATP. ${ }^{19}$ As water continues to accumulate in the cell, small and clear vacuols appear in the cytoplasm which is thought to be a dilated endoplasmic reticulum which widens and protudes outward or by its fractional segment. This picture of nonletal lesions is sometimes called hydropic degeneration or vacuol degeneration. Furthermore, swollen hepatocytes will also appear edematous (balloon degeneration) with lumpy irregular cytoplasm and wide clear cavities. ${ }^{18}$

Green tea (Camellia sinensis) contains high antioxidant compound. Catechin especially Epigallocatechin gallate (EGCG), is the main antioxidant compound in green tea. ${ }^{20} \mathrm{As}$ the antioxidant, EGCG can prevent or reduce oxidative stress due to ethanol consumption in the body through the reduction of ROS prodution, increase in GSH, inhibits the process of alcohol dehydrogenase, and increase catalase metabolism. ${ }^{21}$ Green tea can also suppress various inflammatory chemokines, cytokines, and other inflammatory markers such as: IL- $1 \alpha$, IL-1 $\beta$, IL-6, IL-8, INF- $\gamma$ and C-reactive protein (CRP). So from this process, EGCG which contained in green tea can prevent or reduce the occurrence of liver organ damage due to ethanol consumption. ${ }^{22}$

From the results of data analysis using Shapiro Wilk data normality test $(p>0,05)$ obtained data was not normally distributed so the data transformation test was performed, then proceed with Levene's Homogeneity Test $(p>0,05)$ and obtained homogeneous data, then proceed with Kruskal Wallis hypothesis test and it can be concluded that the hypothesis was accepted, and finally proceed with Post Hoc Mann Whitney test to see whether the data is significant or not. The results obtained were significant at K1 with K2, P1, P2, and P3; P1, P2, and P3 was meaningful towards K1 and K2. Obtained in significant data between P1-P2, P1-P3, and P2-P3 which means giving green tea infusion (Cameliia sinensis) in $\mathrm{P} 2$ and $\mathrm{P} 3$ gave almost the same effect as $\mathrm{P} 1$.

\section{CONCLUSION}

Based on the research, it can be concluded that there was an influence of ethanol on histopathology of white rat liver (Rattus norvegicus) Sprague dawley strain, and there was an influence of giving green tea infusion (Camellia sinensis) on
Journal of Drug Delivery \& Therapeutics. 2020; 10(2-s):90-93

histopathology of white rat liver (Rattus norvegicus) Sprague dawley strain induced by ethanol.

\section{Acknowledgement}

Authors are thankful to Histology and Pathology Laboratory, Medical Faculty of Lampung University for providing facilities to carry out our research.

\section{REFERENCES}

1. Katzung BG, Master SB, Trevor AJ. Farmakologi dasar \& klinik. $12^{\text {th }}$ ed. Jakarta: EGC; 2014. P. 433-447.

2. WHO. Global status report on alcohol and health-2014. Geneva: World Health Organisation; 2014.

3. Stockwell T, Chikritzhs T, Holder H, Single E, Elena M, Jernigan D. 2000. International guide for monitoring alcohol consumption and harm. Geneva: World Health Organization; 2000. P. 1-193.

4. Tritama TK, "Konsumsi Alkohol dan Pengaruhnya Terhadap Kesehatan" Journal Majority, 2014; 4(8):7-10.

5. Depkes RI. Pedoman Pengendalian Tikus. Jakarta: Departemen Kesehatan RI; 2008.

6. Depkes RI. Riset Kesehatan Dasar Provinsi Lampung. Jakarta: Depkes RI; 2018.

7. Nurjanah, Izzati L, Abdullah A, "Aktivitas Antioksidan dan Komponen Bioaktif Kerang Pisau (Solen spp)" IJMS, 2011; 16(3):119-124.

8. Rosalia AA, Indrasari MC, Tangsilan MA, Jayadi T, Danu SS "Pengaruh Infusa Teh Hitam (Camelia sinensis) Terhadap Gambaran Histopatologi Hepar, Renal dan Jumlah Sel-Sel Alfa dan Beta Pankreas Tikus Jantan Sprague dawley Diinduksi Etanol 20\%" Berkala Ilmiah Kedokteran Duta Wacana, 2016; 02(01):243-53.

9. Sánchez EP, Vargas MER, Gutiérrez JCR, "Hepatotoxicity due to Green Tea Consumption (Camellia sinensis)" Rev Col Gastroenterol, 2016; 28(1):43-49.

10. Dobrzynska I, Sniecinska A, Skrzydlweska E, Figaszewski Z, "Green Tea Modulation of The Biochemical and Electronic Properties of Rat Liver Cells That were Affected by Ethanol and Aging" Cell. Mol. Biol. Lett, 2004; 9(4):709-721.

11. Yusni, Husni T, Achmad TH, "Aktivitas Polifenol Teh Hijau (Camellia sinensis (l) o. kuntze) Sebagai Imunomodulator Melalui Respons Supresi Imunoglobulin E (IgE) pada Rinitis Alergika" MKB, 2014; 47(3):160-6.

12. Joung JY, Cho JH, Kim YH, Choi SH, Son CG, "A Literature Review for the Mechanisms of Stress-Induced Liver Injury" Brain Behav, 2019; 9(3):1-8.

13. Szabo G, Mandrekar P, "Focus on: Alcohol and The Liver" Alcohol Research and Health, 2010; 33(1-2):87-96.

14. Bruha R, Dvorak K, Petrtyl J, "Alcoholic liver disease" WJH, 2010; $4(3): 81-90$.

15. Hardman JG, Limbird LE. Dasar farmakologi terapi. $12^{\text {th }}$ ed. Jakarta: EGC; 2012. P. 346-359.

16. Hoek JB, Cahill A, Pastorino JG, "Alcohol and Mitochondria: A Dysfunctional Relationship" Gastroenterology, 2002; 122(7):2049-2063.

17. Sudiono, Kurnia B, Henrawan A, Dijimantoro. Ilmu patologi. Jakarta: EGC; 2014.

18. Mitchell RN, Cotran RS. Jejas adaptasi dan kematian sel. In: Kumar V, Cotran RS, Robbins SL, editors. Buku ajar patologi. $7^{\text {th }}$ ed. Jakarta: EGC; 2007. p. 3-34.

19. Chandrasoma $\mathrm{P}$, Taylor C. Ringkasan patologi anatomi. Jakarta: EGC; 2005.

20. Prasanth MI, Sivamaruthi BS, Chaiyasut C, Tencomnao T, "A Review of the Role of Green Tea (Camellia sinensis) in Antiphotoaging, Stress Resistance, Neuroprotection, and Autophagy" Nutrients, 2019; 11(2):1-24.

21. Lee KM, Kang HS, Yun CH, Kwak HS, "Potential In Vitro Protective Effect of Quercetin, Catechin, Caffeic Acid and Phytic Acid Against Ethanol-Induced Oxidative Stress in Sk1hep-1 Cells" Biomolecules Ther, 2012; 20(5):492-498.

22. Reygaert WC, "An Update on the Health Benefits of Green Tea" Beverages, 2017; 3(4):1-14. 